\title{
A mese és az identifikáció kapcsolata
}

\author{
Herédi Rebeka
}

\section{A mesével kapcsolatos viszonyulási módok, a mese narrativitása}

A mesét többféle szempontból szokták vizsgálni, és többféleképpen szoktak hozzá viszonyulni, ezért természetesen többfajta jelzőt kap, tehát más és más megnevezések illetik. Ezek a közelítések különböző lépcsőfokokra bonhatók attól függően, hogy éppen ki az, aki valamilyen módon, formában kapcsolatba lép a mesével. Abban mindenképp egyetérthetünk, hogy a mese szöveg, tehát befogadásra szánt, és ehhez kapcsolódik az egyik legfontosabb viszonyulási mód, vagyis az, hogy minden mese egy-egy történetet jelöl. Arra, hogy ez a történet tulajdonképpen mit takar, milyen lehetőségeket rejt, a későbbiekben szeretnék kitérni.

Tehát a mese befogadásra szánt szöveg. Ez minden szövegröl elmondható, elmondható egy címkéről vagy egy hirdetésről, amit épp az utcán látunk, azonban ezeknél a szövegeknél nincs meg az a hajlam, hogy azonosuljanak az olvasóval, csupán információt közölnek. A mesének viszont mint irodalmi szövegnek az egyik alapvető célja az, hogy azonosuljon az olvasójával, vagy a hallgatóságával. A továbbiakban részletesebben ki szeretnék térni arra, hogy ez az azonosulás hogy megy végbe, valamint arra, hogy egyáltalán miért van szükség rá.

Az elöbbiekben utaltam arra az egyszerü tényre, hogy a mese szöveg, méghozzá egy olyan szöveg, ami mindig valamilyen történetet mond el. És ez az egyik kulcsszó, ha meg akarjuk érteni, hogy a mese valójában miért olyan sikeres, és miért gyakorol olyan nagy hatást az emberekre, és ez egyáltalán hogyan megy végbe.

A folyamat akkor kezdődik, amikor elkezdünk mesélni. Ez egy olyan kezdés, ami máris megragadja a figyelmet, hiszen nem egy egyszerü szöveget kezdünk el mondani, hanem olyat, ami történetbe kezd. Ha valaki valahol egy száraz előadás közepén valami történetbe kezd, máris megragadja a hallgatóság figyelmét, egyszerüen azért, mert fogékonyak vagyunk a történetekre, vagyis narratív lények vagyunk. Ez pedig az evolúció során alakult ki, még az őskorban. Képzeljük el, hogy egy férfi hazajött a vadászatból, és a tüz körül elmondta a többieknek, hogy találkozott valami veszélyes állattal, ez a találkozás pedig védekezésre késztette, vagyis valamit tennie kellett, hogy ne legyen áldozat. Ezt tehát elmesélte a többieknek, akik a történetmesélés közben közvetett ta- 
pasztalatra tettek szert. Vagyis nem kellett ott lenniük, nekik is átélniük, de ha valamikor ők is ebbe a helyzetbe kerülnek, tudják majd azt alkalmazni, amit itt megtanultak. Ezt értem közvetett tapasztalatszerzés alatt.

Ha ezt az ismeretanyagot átültetjük a mesékre, akkor könnyen rájöhetünk arra, hogy ott is hasonló dolgok esnek meg. Egyrészt máris megragadjuk egy gyermek figyelmét, ahogy mesélni kezdünk, másrészt az ő agyában is hasonló folyamatok fognak megesni.

\section{A mese világa, komfortzóna és annak elhagyása, avagy ismert és ismeretlen találkozása}

A mese esetében a kezdés mindig távolító. Ez a távolítás pedig rendszerint a világtól távolít el minket, ahol a mindennapjainkat éljük. A következő távolító formulákkal találkozhatunk: Egyszer volt, hol nem volt vagy Volt egyszer egy, és így folytatódhat: hetedhét országon túl, ahol a kurta farkú malac túr. Rengeteget tudnánk idesorolni, most azonban csak jelezni szeretném, hogy ez a kezdés funkcióval bír, felkészíti a hallgatót arra, hogy itt most olyan történetet fog hallani, ami ebben a formában ezen a világon nem eshet meg, vagyis egy olyan világba kalauzolja, ami bizonyos szinteken eltér az „evilágitól.”

Ez az eltérés, ha alaposabban vizsgáljuk a mesét, csak részleges, de mondhatnánk úgy is, hogy csupán szimbolikus. Vagyis a mese szimbólumokkal telített világot tár fel, ezt a szimbolikus világot pedig minden gyermek kitünően tudja értelmezni, és átfordítani azt a saját világára. A mese világának egyik legfontosabb jellemzője az, hogy nem problémamentes, sőt problémával kezd, amit meg kell oldani. A mese világában még találkozhatunk bizonyos szereplőkkel, terekkel, helyszínekkel, tárgyakkal, amik a mese esetében tipikusak. Egy varázsmese esetén ilyen például a sárkány, boszorkány, törpe, különböző varázstárgyak. A lényeg az, hogy a mesehős világgá megy, és többnyire mindennel találkozik, amivel találkoznia kell. Ezen a ponton szeretnék egy nagyon fontos momentumra kitérni, vagyis arra, hogy minden mesehősnek ki kell lépnie a saját komfortzónájából, el kell hagynia azt a közeget, amiben eddig volt. Ezt a közeget kétféleképpen lehetne jellemezni: biztonságot ad, de éppen emiatt nem ismerünk meg egy idő után semmi újat, ami kihívást jelentene számunkra, ez egyszersmind azt is magában foglalja, hogy innen ki kell lépnünk. Ez a kilépés legtöbbször valamilyen késztetés hatására megy végbe, vagyis a körülmények, amelyeket már megszoktunk és jól ismerünk, megváltoztak, és azt kínálják fel nekünk, hogy oldjuk meg öket, hogy megint minden rendben 
legyen. Ez a mozzanat azonban magával hozza azt az egyszerü, de kézenfekvő következtetést, hogy már semmi sem lesz olyan, mint régen. Tehát pontosan azokat a körülményeket már nem tudjuk újra felállítani, még a probléma megoldása után sem, hanem egy egészen új körülményhalmaz fog létrejönni. A szereplő körül tehát minden megújul, ezt a megújulást pedig ő maga keltette életre. Itt szeretném hangsúlyozni, hogy a megújult körülmények közepén egy megújult énnel állunk szemben, aki miután világgá ment, tehát világot látott (újat tapasztalt), próbatételekkel, szörnyekkel, gonoszokkal és jókkal találkozott. A mesében minden dolognak, térnek, helynek, karakternek van valamilyen szerepe. A próbatételeknek, az akadályoknak az a céljuk, hogy legyőzzük őket, és menjünk tovább, a mesei terek legtöbbször jelentéssel telítettek, az erdö például az elveszettséget szimbolizálja. Ha ezen egy kicsit elgondolkodunk, könnyen rájöhetünk arra, hogy ezek a terek legtöbbször valamilyen lelkiállapotot sugallnak, vagyis azonos képet mutatnak a föhős lelkiállapotával. Ugyanis amikor a hős az erdőben van és bolyong, és elveszett, akkor valójában nemcsak elveszett, hanem elveszettnek is érzi magát, vagy, ha valakit bezárnak valahová, akkor valóban úgy érezheti magát, hogy nem tud mit lépni, be van valahova zárva, de mondhatnánk egyszerüen úgy is, hogy szorult helyzetben van, ebből pedig előbb-utóbb ki kell lépni.

Itt szeretnék kitérni a bevezetésben megkezdett gondolatmenetre, miszerint a mese történet. A mese valamit elmond, elmesél. Ez a történet a saját világában zajlik, aminek megvannak a saját müködési elvei, szabályai. Már azt is kifejtettem, hogy mikor a mesét hallgatjuk, a mindennapi világtól eltávolodunk, és ezzel egy időben belépünk a mesék világába. Ez a belépés viszont csak egy módon lehetséges, ha azonosulunk a szereplövel, vagyis könnyen lehet, hogy az eltávolodás azért olyan fontos, hogy ez a mozzanat egyáltalán végbe tudjon menni. Megvalósul tehát a beleélés fázisa, ami kulcsfontosságú, hiszen itt történik meg a két világ közötti átjárás. Minden gyermek rendelkezik ugyanis azzal az egyszerü tulajdonsággal, hogy a történethallgatás közben át tudja élni az eseményeket, próbatételeket, vagyis miközben a mesét hallgatja, a képzelet szintjén bár, de ő is legyőzi a szörnyeket, túljár néhány szereplő eszén, mígnem eljut a feloldáshoz, a boldog véghez, méghozzá úgy, hogy azt is megtapasztalja. Mindebböl az következik, hogy az ott szerzett tapasztalatokat tudja kamatoztatni a való életben. A történet végén legtöbbször levon valamilyen tanulságot, és feldolgozza az ott hallottakat.

Az előbb elmondottakhoz csatlakoznak még az olyan készségek, képességek fejlődései, mint a képzelőerő - miközben mesélünk valakinek, az agy szintjén minden lejátszódik -, a kifejezőkészség, gyarapodik a szókincs. 
A mese kontextusai

A továbbiakban szeretnék még egy nagyon fontos elemre kitérni, ez pedig a mese kontextusa. Ez a kontextus napjainkban legtöbbször a családra korlátozódik, vagyis a szülők mesélnek a gyermekeknek. Érdemes megvizsgálni az interakciót, ami rendszerint létrejön akkor, amikor mesét hallgatunk. Egyrészt megragadjuk a másik figyelmét, másrészt pedig minden szülőnek megvan a lehetősége, hogy figyelje a gyermek reakcióját, miközben az a mesét hallgatja. A szülő ebben az esetben mint közvetítő van jelen, közvetít a mese világa és a gyermek között, így mint résztvevő van jelen ebben a helyzetben.

Ez a mese egyik legalapvetőbb kontextusa, további kontextusa még a televízió, ami azonban már korántsem biztosít olyan lehetőségeket, mint ha valamilyen mesét hallgatnánk vagy olvasnánk, hiszen a televízió esetében már előre megadott képi világgal találkozhatunk, ráadásul a legtöbb televízióban leadott mese nem rendelkezik tipikus mesei elemekkel, vagy egyáltalán mesemenettel, amik szükségesek lennének. Minden mesének van ugyanis egy tipikus elöremenetele. Idetartozik például annak a jelzése, hogy valamikor valahol élt valaki boldogan, majd jön egy probléma, ami ezt megtöri, majd jön a rend helyreállítása, és az új rend kialakítása.

Ez tulajdonképpen lefedi a mese modernkori kontextusait, azonban, ha egy kicsit visszamegyünk az időben, azt tapasztalhatjuk, hogy a mesének volt egy sokkal közösségibb jellege, vagyis az emberek valamilyen közös munka során meséltek egymásnak, szórakoztatás gyanánt. Itt érkezünk el ahhoz az egyik alapvető jellegzetességhez, hogy a mese szájhagyomány útján terjedt, vagyis lehetősége volt a folyamatos megújulásra, mindenkinek lehetősége volt formálni a mesét, hozzátenni valamit, vagy éppen elvenni, hiszen a szóbeli forma által a kötöttség is kevesebb volt.

\section{A mese mint a formálódás eszköze}

A fejlődés legtöbbször az átmenetiséggel hozható kapcsolatba, ugyanis csak az formálható, aki az egyik fejlődési pontról át tud billenni a következő fejlődési pontra. Eszerint a következtetés szerint tehát az ember az élete során különböző stációkon halad keresztül, és kétség sem fér hozzá, hogy az egyik legfontosabb ilyen szakasz nem felnőttkorban, hanem inkább gyermekkorban kap nagyobb hangsúlyt.

A mese hőse és a gyermek között rengeteg párhuzam vonható, és az egyik pont ezzel a fejlödni akarással van összhangban. A mese kitünően szimbolizálja azt, hogy a fejlődést mint folyamatosan tartó szakaszt kell szemlélnünk, ahhoz 
azonban, hogy kezdetét vegye ez a folyamat, nemcsak testi, hanem szellemi, mentális síkon is el kell indulni.

A mese tökéletes világot kínál fel a gyermekek számára, hiszen ellentétekkel tarkított világképpel dolgozik (jó és rossz, csúf és szép, gazdag és szegény stb.), ahogyan a gyermeki gondolkodás is, valamint élénk fantáziaképekkel, csodákkal tarkított világot tár fel, amire szintén hasonlít a gyermeki gondolkodásmód, így könnyen beláthatjuk, hogy minden gyermek számára rendkívül könnyen végbemegy a mese világával való azonosulás. Azonban ez nemcsak konkrétan a mese világáról mondható el, hanem ugyanúgy érvényes a hősre is, akiknek néha a „saját személyiségükön belül megbomlott egyensúlyt kell rendezniük: akinek a félelemből van kevés, annak meg kell tanulnia félni, aki a haláltól retteg, annak az életet kell megtanulnia szeretni és élvezni, a túl erős és a túlságosan lusta szintén a mérték mibenlétéről kap leckét a mesei út bejárása során" (Boldizsár, 2004, 15. o.).

A mese rengeteg választási lehetőséget kínál fel a mesehős, de a gyermek szempontjából is. Az egyik ilyen választás a befogadó perspektívájából, hogy van lehetősége kiválasztani azt a szereplöt, akivel ő azonosulni kíván, ez - ahogyan már korábban is utaltam rá - az lesz, aki számára a legszimpatikusabb. Ez természetesen magával hozza azt a kézenfekvő következtetést, hogy tudat alatt az olvasóban vagy a hallgatóban fel fog ébredni az a vágy, hogy ne csak szimpatizáljon a kiválasztott karakterrel, hanem kezdjen rá hasonlítani is. Teszi mindezt úgy a mese, hogy közben a két fontos szereplőt, vagyis a gyermeket és a mesehőst nem választja el élesen egymástól, ugyanis ők több mindenben hasonlítanak. Az egyik ilyen nagy hasonlóság szokott lenni az, hogy az adott mesehős gyakran gyermek, vagyis körülbelül egyidős a mese hallgatójával, a másik a tulajdonságok, az érzelmek, amelyek bele vannak sürítve az adott mesébe, vagy éppen az, hogy a mesehős mint olyan, hibákat követ el, amiket aztán van lehetősége kijavítani, korrigálni.

Itt szeretnék egy nagyon fontos mesei jellemzőre kitérni: a mese egy tömör világot sürít magába, problémával kezd és feloldással zárul. A mesei világ általában a végletekből táplálkozik, ahogyan arra már az előbbiekben is utaltam, erre Nagy Olga is felhívja a figyelmet, szerinte a mese nem más, mint ,a valóság lényegének a megragadása" (Nagy, 1974, 7. o.).

A mesében nagyon sok minden megtörténhet, és nagyon sok minden meg is történik, éppen ezért a mesékben semmit sem tekinthetünk véglegesnek, ugyanis bármikor megtörténhet valakinek a feltámadása (ami egyébként a mesehős esetében a személyiség újjászületésével vonható párhuzamba), a szétkaszabolása, átváltoztatása stb. Éppen ezért feltételezhetnénk azt, hogy a mese alapvetően egy borzalmas világot ábrázol, nem való gyerekek kezébe, mert nem ad 
számukra biztonságot, és elkezdenek félni. Itt nagyon fontos azt kiemelni, hogy a hagyományos mese egyik legnagyobb erénye, hogy csak szöveggel él, amiket például a szülök fel szoktak olvasni, és ez a szöveg rendszerint mellőz minden olyan fölösleges elemet, ami esetleg megrémiszthetné a gyereket, például nem szokták részletezni, miként tépte szét a madár a mesehős testét, csupán megjegyzik azt. Természetesen egyre népszerübbek a képes mesekönyvek, azonban ezek sem ezt az oldalát fogják megragadni a meséknek. Polcz Alaine $(2009,85$. o.) utal rá, hogy „a helyes pszichológiai megoldás és a jó müvészi megoldás pontosan fedik egymást. Mert nemcsak lélektani, hanem esztétikai, mủvészi szempontból is akkor kielégítő a félelmes ábrázolása, ha funkciója van, megfelelő a stílusa, és arányosan illeszkedik az egészbe." A fenti gondolatokhoz még hozzátenném azt, hogy véleményem szerint éppen azért jó például mesét olvasni vagy hallgatni (nem pedig televízióban nézni), mert így a hallgató vagy az olvasó a saját fantáziája segítségével olyan képeket fog a mese alapján magának kreálni, ami számára elegendő, de megkapó.

A mese tehát tökéletesen illeszkedik a gyermek gondolkodásmódjához, valamint világszemléletéhez, az,,5-7 éves gyermek az irodalmi olvasmánytól érdekes cselekményt vár, akár a mesék irreális, akár a való élet reális világában játszódik. Szereti a képzeletét erősen foglalkoztató mesés elemeket s az érzelmi életére erősen ható érdekes, izgalmas, szomorú vagy vidám mozzanatokat, a humort és játékosságot, s mindenekfelett az optimista megoldást" (Petrolay, 1978, 90. o.).

Az optimista megoldás a mesétől az egyik legnagyobb követelésünk, ugyanis ez adja meg a végső feloldást a hallgatóság számára, de mindenekfelett ez lesz azon elem, aminek köszönhetően a való világba történő visszacsöppenés megtörténik. Még egy nagyon fontos jellegzetességre hívja fel a figyelmet: mindig az optimista véget, vagyis megoldást várjuk az adott mesétől, éppen ezért a gyermek pár mese meghallgatása, elolvasása után biztonsággal állíthatja, hogy egy mesének akkor van vége, mikor ez az optimista vég bekövetkezik. Ez a mese szerkezetére vonatkozó egyik legfontosabb kritérium, mert nemcsak a saját megszerkesztettségének mondana ellent, ha mindez a pozitív vég nem történne meg, hanem a gyermeki gondolkodásmódban is igen nagy csorbulás menne végbe. Egyrészt nem lenne meg a kalandok, veszteségek utáni feloldás, tehát a boldogság elérése, amik ily módon már hiábavalónak tủnnének. Azonban a mese a boldog véggel, vagyis az optimista kicsengéssel a gyermek számára egy tökéletes életvezetési sémát nyújt, miszerint a küzdelmek után elérheti azt, amire vágyik, de csak akkor, ha cselekszik, vagyis tesz érte. A mese tehát kimondja azt, hogy ez a boldogság bárki részére elérhető, ha merünk tenni. Ezt a gondolatmenetet, ami egyébként a meséé, a gyermek magáévá teszi, 
és a saját életét tudja ráépíteni, így világossá válik számára, hogy valamilyen problémának csak akkor van vége, ha boldognak érzi magát az adott szituációban, vagyis a probléma megoldódott.

Fentebb már említettem, hogy a saját megszerkesztettségének mondana a mese ellent, ha nem boldog véggel érne véget, ugyanis a mese mindig egy kerek egészet ír le, vagyis a mese egy tökéletesen komponált történet, aminek vannak különböző, várt fordulatai, szintjei. Ilyen a mese eleje, vagyis a probléma beköszöntése, a kalandok sora (ez a mese közepe), majd a mese vége, ami tehát boldog. A mesében elvégre is hiába vannak végletek, ellentétek ábrázolva, úgy hogy közben minden megtörténik, ami csak megtörténhet, ezt a strukturáltságot nem rúghatja fel. „A mesei világ nagy lazasága, korlátokat és határokat nem ismerő volta csak a mese gondolataira és tartalmára érvényes: a mese fölépítése a rend világához tartozik" (Honti, 1975, 70. o.).

A mese és a gyermeki figyelem tökéletes összhangot alkotnak, ugyanis mivel a mese él a tömörítés eszközével, így végül egy sürített, rövid történetet fogunk kapni, ami a maga cselekményességével megragadja a gyermek figyelmét, és feltehetöleg fent is tartja azt egészen a mese végéig. Azonban ez már nem lenne akkor elmondható, ha egy regényt szeretnénk felolvasni egy gyermeknek, egész egyszerűen azért, mert a koncentrációs képessége mindezt nem tenné lehetővé. Vagyis a mese éppen olyan hosszúságú, mint amilyent a gyermek koncentrációs képessége elvár.

A mesélés során gyakran találkozhatunk azzal, hogy a gyermek azt szeretné, ugyanazt a mesét olvassuk fel neki, amit már egyszer vagy többször megtettünk. A mese előnye minden más történettel szemben az, hogy mindent szimbolikus formában közöl, ez a szimbolikus közlés azonban magában hordozza azt, hogy a gyermek, mikor elsőnek hall valamilyen mesét, nem biztos, hogy minden egyes szimbólumot vagy történést le fog fordítani magában. Ez lehetőséget ad arra, hogy aminek a befogadására még nem érett meg a gyermek, azt figyelmen kívül hagyja. Ez lehet az egyik oka annak, hogy azt szeretné, még egyszer olvassuk fel neki, ez segíti a fokozatos megértést.

A gyermeki gondolkodásban az externalizáció hangsúlyos szerepet kap, ez legtöbbször a tudattalan tartalmak felszínre kerülésével hozható kapcsolatba. Amikor egy-egy ilyen tudattalan tartalom a felszínre kerül, a gyermek mindig próbálja azt valamilyen módon kívülre helyezni, például babákkal, különböző játékokkal. Ezek a játékok testesítik meg a tudattalan tartalmak bizonyos részeit, ezzel segítve azok feldolgozását. A legjobban akkor győződhetünk meg arról, hogy az adott mese elérte kívánt hatását, ha azt a gyermek kívülre tudja helyezni, ez leggyakrabban egy-egy mese eljátszásával szokott megtörténni (Büki, 2009). 


\title{
Felhasznált irodalom
}

Boldizsár Ildikó (2004): Mesepoétika. Akadémiai Kiadó, Budapest.

Büki Péter (2009): A népmese és a gyermek. In: Szávai Ilona (szerk.): Mint a mesében? Pont Kiadó, Budapest. 29-44.

Honti János (1975): A mese világa. Magvető Kiadó, Budapest.

Nagy Olga (1974): Hösök, csalókák, ördögök. Kriterion Könyvkiadó, Bukarest.

Petrolay Margit (1978): Gondolatok a gyermekirodalomról. Tankönyvkiadó, Budapest.

Polcz Alaine (2009): A gyógyító mese. In: Szávai Ilona (szerk.): Mint a mesében? Pont Kiadó, Budapest. 50-51.

\begin{abstract}
The relationship between the tales and the identification

There is a wide variety of how you thinking about tales: you can regard them as plain texts, literary work, or even stories. The three approaches are interlinked, and this study will mainly examine the tale as a literary work and as a story. During reading and listening of a tale, different gates of education are opened. By its very nature, a tale is connected to the child thinks, thus giving the possibility of identification.
\end{abstract}

